\title{
MODELS OF TRAPS FOR THE COCONUT PESTS RHYNCOPHORUS BILINEATUS AND SCAPANES AUSTRALIS AND THEIR TRAPPING EFFICIENCY IN PAPUA NEW GUINEA
}

\author{
Titus Kakul ${ }^{1 /}$, Dr. S. Laup ${ }^{2 /,}$ Mr. R. N. B. Prior ${ }^{2 /}$. Dr. Didier Rochat ${ }^{4 /}$, \\ Dr. Jean Paul Morin, ${ }^{(3)}$, P. Gende, S. Embupa ${ }^{(2)}$ \& Dr. L. Ollivier ${ }^{(3)}$
}

\begin{abstract}
The beetle pests Scapanes australis, Oryctes rhinocerous and Rhyncophorus bilineatus have been major constraints to coconut production in the Islands region of Papua New Guinea for the last 30 years. Efficient synthetic attractants able to lure and trap all three beetles have been developed. This paper describes several trap designs developed at the Cocoa and Coconut Research Institute and the results obtained for their trapping efficiency in the laboratory and the field. A modification of the "Titus Bucket" trap increased the number of $R$. bilineatus caught threefold and of female Scapanes twofold. PVC pipe traps caught more Scapanes than the modified "Titus Bucket" trap.
\end{abstract}

The importance of well design traps and their use for specific purposes are discussed.

Key words: Coconuts, Scapanes australis, Oryctes rhinoceros, R. bilineatus, traps, synergist.

\footnotetext{
1/ Cocoa \& Coconut Research Instutute (CCRI), P. O. Box 642, Madang, Papua New Guine.a Email: ccriento@datec.net.pg;

2/ Cocoa \& Coconut Research Institute (CCRI), P. O. Box 1846, Rabaul, Papua New Guinea;

3/ Centre International de Recherche Agronomique pour le Developpement (CIRAD-CP), TA 80/PS3, Bd de la Lironde 34398, Montpellier Cedex 5, France; Email: : ollivier@cirad.fr;

4/ Institut National de la Recherche Agronomique (INRA) UR 258, 78026, Versailles Cedex, France. Email:
} 


\section{INTRODUCTION}

The Islands region is a major copra producing area in Papua New Guinea (PNG). A number of beetle pests are a constraint to production. The boring into coconut crowns by Scapanes australis Boisd (Col.,Scarab.) and Oryctes rhinoceros Linn (Col.,Scarab.) is usually followed by damage from Rhynchophorus bilineatus Mont. (Col., Curcul.). They mainly attack and kill young coconut palms (Prior. et al., 2000) preventing new planting for rehabilitation of old coconut plantations. The damage from $R$. bilineatus is often severe and palms may even die.

Field experiments for trapping $R$. bilineatus began in the PNG Cocoa and Coconut Research Institute, Rabaul (CCRI) in 1991 (Anon., 1991). However, after six years of trapping and many thousands of $R$. bilineatus lured into traps, there was no reduction in pest damage levels (Anon., 1993). It was later observed that the traps used were not efficient, catching only $10 \%$ of the beetles that flew towards them (Anon, 1998). Therefore, this study was initiated to determine trap designs and various attractants to increase trapping efficiency in the field.

\section{MATERIALS AND METHODS}

Four Designs Rhynchophorus trap (Figure 1) were tested. Trap one was the Laup bamboo trap (LBT) which consisted of one inter-node of giant bamboo, with two entry holes $(5 \mathrm{~cm}$ width and 10 $\mathrm{cm}$ height) on opposite sides, $20 \mathrm{~cm}$ from the bottom internode. The second trap was the Oehlschlager Palm Weevil Trap (OPWT) which is made up of a 10-litre bucket with entry slots $(2 \mathrm{~cm}$ in width, $5 \mathrm{~cm}$ length) in the sides and a lid (Oehlschlager. et al., 1993). Trap three, the Prior Dynastid Trap (PDT), is made up of a 10-litre bucket with (two entry windows $13 \times 7.5 \mathrm{~cm}$ cut in the sides $15 \mathrm{~cm}$ above the base and two small slits about $5 \mathrm{~cm}$ up from the base, to allow excess water to drain out. Trap four is the Titus Compound Bucket Trap (TCBT) (Kakul. et al., 1999) that included a food container (height $19 \mathrm{~cm}$, top diameter $21 \mathrm{~cm}$ and base diameter $16 \mathrm{~cm}$ ) with many small holes approximately $0.5 \mathrm{~cm}$ apart in it for air circulation inside the PDT.

\section{Attractants}

The attractant mixture used in all field trials consisted of the insect pheromone with host plant material as the co-attractant. The beetle pheromones were:

S. australis : 90:5 v/v of 2-butanol and acetone (Rochat, et al, 2000);

$R$. bilineatus: 4-methyl-5-nonamal (Oehlschlager, et al., 1995);

O. rhinoceros: Ethyl 4-methyloctanate (4-MOE) (Hallet, et al., 1995, Morin, et al., 1996).

The host plant co-attractant was two pieces of split sugarcane stalk or two pieces of split coconut seedling crown.

\section{Laboratory assay}

The efficacy of four different trap designs was first evaluated in the laboratory for their beetle retention. Three retention agents were treatments for: 1) Control (no retention agent); 2) water only; and, 3) soapy water. The treatment combination was factorial giving twelve treatments. Each treatment was replicated three times and 10 BPW were placed in each trap. The number of weevils remaining in the traps was counted daily for seven days.

The efficiency of TBT and the PDT, designed to trap dynastids, were compared in the laboratory for the retention of Scapanes. The retention agents were water and soapy water placed in the traps. The treatment combination was factorial giving four treatments. There were ten replicates (ten traps) of each treatment and six (3 male and 3 female) adults of Scapanes placed inside each trap. The traps were hung in the laboratory, and the Scapanes present in the trap were counted daily.

\section{Field testing of traps}

\section{Field Trial sites}

Trials 1 and 2 were carried out consecutively under cocoa and young coconut stands at block 12, Tavilo plantation, East New Britain Province, Papua New Guinea in 1998. The traps were cleared on a weekly basis. Trial 3 was carried out at Kervera plantation, not far from Tavilo, in 2000. The plantation consists of intercropped cocoa and coconut. The field testing of Scapanes trap was carried out in a block of cocoa 
and young coconut at Tokiala, plantation 600 metres to the north of Tavilo.

The traps were placed 50 metres apart. Bucket traps were either hung on a cocoa branch or coconut leaf petiole 1.5 metres above the ground. The PVC traps were placed on the ground, supported with wooden pegs.

\section{Field Trials}

In Trial 1 the traps were modified by wrapping fibrous coconut leaf sheath (being referred to as bilas [BL]) (Figure 2) in a replicated trial. The four treatments were as follows; 1 . TBT, 2. LBT, 3. BL TBT, 4. BL LBT. The trial design was a complete randomised block with 12 replications.

In Trial 2 the relative efficiency of shelves (S) attached to palm weevil traps as a landing surface for the weevils was examined in a replicated experiment. The four treatments were as follows; 1) BL, OWT; 2) BL, OWT and S; 3) BL, OWT, S; and four live $R$. bilineatus weevils in each trap (2 males and 2 females); and, 4) TBT. The trial design was a complete randomised block with 12 replications.

Field trial 3 examined the relative efficiency of the BL TBT in trapping the three beetle pests of coconut in Kervera plantation (100 metres south of Tavilo) in 1998. The TBT was designed to capture both the black palm weevil and the two dynastids and was thus chosen for further testing in the field. The two treatments were: 1) BL TBT; and, 2) TBT. There were 25 replications (traps) and the trial design was completely randomised.

Field trial 4 examined the efficacy of the new Scapanes trap designs. A PVC tube was used to construct this trap (Figure 3) and the TBT was used as a standard trap. The treatments were 1) Titus Bucket Trap (TBT); 2) PVC Pipe Large (PVCPL) $15 \mathrm{~cm}$ diameter X $200 \mathrm{~cm}$ length. 3) PVC Pipe Medium (PVCPM) 10-cm diameter X $200 \mathrm{~cm}$ length. There were twelve replications and the trial was a completely randomised design. The traps were placed 50 metres apart.

All the beetle count data were transformed using the square root transformation and then subjected to ANOVA using the Microsoft Excel Data Analysis Function.

\section{RESULTS}

\subsection{Laboratory Test}

The results from laboratory assays showed the use a of soapy water as a killing agent gave absolute mortality in the Oeshlschlager and Titus traps (Figure 4). Retention was high (50\%) in LBT traps compared to the other designs tested. With the addition of pure water, the TBT and OWT traps retained more than $50 \%$ of the test insects. The best results were observed with the use of soapy water which resulted in $100 \%$ mortality in the TBT and OWT, but only $83 \%$ in LBT traps. The detergent in soapy water lowers surface tension and promotes wetting of beetles, resulting in drowning.

The laboratory test results for Scapanes indicated that TBT gave absolute retention even without a killing agent (Figure 5). The TBT appeared to retain all the test insects, whereas the PDT was poor without a killing medium. Insect mortality was high in both traps when soapy water was used, but was low without a killing agent.

\subsection{Field Assays}

The effect of modifying the traps by wrapping fibrous coconut pads to provide landing surfaces and a visual cue for $R$. bilineatus adults was clearly demonstrated with highly significant $(\mathrm{P}<0.01)$ increase in the number of weevils caught in the modified traps than the standard traps. The modified TBT (TBT BL) was catching significantly $(\mathrm{p}<0.01)$ more $R$. bilineatus adults than the other traps (Figure 6). The other traps, especially LBT trap, was shown to be poor in catching these weevils. No differences in catch were observed between the TBT and LBT BL.

In Trial 2 the effect of platform on trap entrance as a landing surface was not significant (Figure 7). The effect of resident weevils on retaining weevils captured was significant $(\mathrm{P}<0.01)$.

The efficacy of TBT (Trial no. 3) in trapping all three beetles showed that modified traps caught significantly $(\mathrm{P}<0.01)$ more $R$. bilineatus than the standard trap (Figure 8). The modified trap also caught significantly more female Scapanes and $O$. rhinoceros than the standard traps. The number of Scapanes caught in both trap types did not differ significantly. 
In trial 4 the trap effect was highly significant $(\mathrm{P}=0.01)$, with the two PVC Trap designs catching more beetles than the TBT (Figure 9). Pieces of sugar cane were hung inside the PVC Traps as kairomones and this helped improve insect catches.

\section{DISCUSSION}

Preliminary screening of the various Rhynchophorus traps in retaining weevils clearly demonstrated the importance of a well-designed trap, which would minimise the number of beetles escaping. A low number of beetles present in the plantation can still cause economic damage to coconuts. The results obtained further suggested the importance of using appropriate trap and killing agents for specific uses. For instance, TBT and OWT can be used in situations where the objective of trapping is lure and kill. When the objective of trapping is to release entomopathogens via traps then PDT and LBT are more appropriate as the insect can go into the trap, get itself contaminated and then escape. The PDT had been used successfully to spread the Baculovirus among Oryctes rhinoceros in East New Britain province in the past (Prior. Et. Al.1995).

TBT gave complete retention for Scapanes even without a retention agent. It is appropriate for trapping Scapanes in tropical conditions where the liquid retention agents tend to dry up rapidly. Liquid retention agents are not necessary when the traps are intended to catch Scapanes.

Bilas Traps mimic the natural host of the beetles where resident weevils in wounds of host are inconspicuous and the emigrant insect would have to crawl into the palms guided by chemical cues. The non-bilas trap used in the past did not lack attraction but failed to capture the weevils. This was because the weevils require a landing surface to alight on and then crawl into the traps. It is possible that the pheromone could have drawn in many more weevils from outside the immediate trapping area. This may explain why mass trapping of $R$. bilineatus in the past was not effective in reducing losses of coconuts (Anon, 1998). Bilas not only enhanced the efficacy of the traps but also increased the durability of the bucket traps by protecting them from direct solar radiation.
The use of shelves or pads as landing surfaces for the weevil resulted in a reduction in the number of weevils caught. The platform may provide an opportunity for the beetles to alight and then fly off again. The resident weevil in traps (treatment 3) did not enhance captures relative to the bilas trap (treatment 1), but their effect in retaining the weevils in the trap relative to bilas and shelves (treatment 2) was significant $(\mathrm{p}=0.5)$. This implied that shelves are not a necessary part of the trap.

Sole trapping of individual species is costly and inappropriate in the case of the coconut beetles as they share the same habitat and attack the same plant. A highly positive correlation of attack between the weevil and the two dynasties has been shown (Kakul, et al, in preparation). However as the synergist plant material was not the same for Oryctes rhinoceros (Alfiler, 1999, Sudharto. et al. 2001), this pest should be trapped with a different trap combining 4-MOE and empty oil palm fruit bunch (EFB) (Morin. et al. 2001). If $\mathrm{EFB}$ is not available, rotting palm trunk can be used (Alfiler, 1999). For $R$. bilineatus and $S$. australis, the TBT was selected to be further tested in the field because the two insects use the same plant material synergist (fresh coconut bulb or pieces of sugarcane).

BL TBT caught more female Scapanes than the non BL TBT. The difference is huge in terms of the ability of Scapanes to sustain its population

and continue to cause economic damage to the coconut cultivation. A coconut can die if it is attacked by a Scapanes and the wound is than infested by $R$. bilineatus. The Scapanes attack coconuts for up to seven years and a female Scapanes lays an average of 52 eggs.

The PVC trap can now be used to trap the three beetles. A synthetic synergist for the $O$. rhinoceros beetle is not yet available and rotting coconut wood parts can be used as a pheromone synergist and in the PVC trap. The PVC trap may look like an old coconut trunk in the dark. The three beetles cannot escape once caught in the dark because of the limited space available for them to manoeuvre (rotting coconut trunk parts at the bottom of the traps). The trap can remain in the field for at least two months as long as the 
attractants do not run out. Killing agents such as water or insecticides are not necessary in this trap.

The cost of PVCL was (US \$12), three times the cost of TBT (US \$4) and twice the cost of PVCM (US \$6). However, the PVC pipes traps are more durable than the bucket traps. The correct dimensions of PVCM traps were not followed when making the traps. Manufacturing the PVCM trap using the right measurements will increase the beetle catches to the same level as PVCL, thus further reducing the cost of PVC traps.

\section{ACKNOWLEDGEMENTS}

R. Minana and entomology section labourers for persistent commitment to field trapping and assessment. Coconut Products Limited and NewMark Plantation Management Ltd. for allowing us to use Gunanur and Tokiala plantations, thus providing the necessary coconut field experimental sites. This paper is published with the permission of the Directors of PNG CCRI. We are also indebted to the European Union for funding under INCO project Number RB-IC 18CT970199 and Dr. Y. Efron, Dr. L. Kuniata, Mr. M. Powell for comments on the manuscript.

\section{References cited}

Alfiler, A. R. R. (1999). Increased attraction of Oryctes aggregation pheromone, Ethyl 4 methyloctanoate, with coconut wood, CORD 15(2): 106-114.

Anon. 1991. Annual Report of the Papua New Guinea Cocoa and Coconut Research Institute.

Anon. 1998. Annual Report of the Papua New Guinea Cocoa and Coconut Research Institute.

Hallet, R.H., Perez, A.L., Gries, G., Gries, R., Pierce, H.D. Jr., Yue, J., Oehlschlager, A. C., Gonzalez, L.M., Borden, J.H., (1995). Aggregation pheromone of the coconut rhinoceros beetles Oryctes rhinoceros (L) (Coleoptera: Scarab). J. Chem. Ecol. 21: 1549-1570.
Kakul, T. K., Laup, S., Stathers, T., BeaudoinOllivier, L., Morin, J. P., and Rochat, D. (1999). Trapping and disruption of the mating activity of Scapanes australis using live male as bait in Papua New Guinea. CORD 15 (2), $131-145$.

Kakul, T.K., Laup, S., Prior, R.N.B. Rochat, D., Morin, J.P., Embupa, S., Gende, P., and, Ollivier, L.; The Impact of Olfactory Trapping Scapanes australis: A major pest of coconut in Papua New Guinea (In preparation)

Morin, J.P, Sudharto, P.S., Purba, R, Desmier de Chenon, T. Kakul, S Laup, L. BeaudoinOllivier and, Rochat, D.; 2001. A new type of trap for capturing Oryctes rhinoceros (Scarabaeidae, Dynastinae), the main pest in young oil palm and coconut plantings. CORD, 17(2): 13-21.

Morin, J.P., Rochat, D., Malosse, C., Lettere, M., Desmier de Chenon, R., Wibowo H., and, Descoins, C. (1996). Ethyl 4methyloctanoate, major component of Oryctes rhinoceros (L.) (Coleoptera, Dynastidae) pheromone. C.R. Acad. Sci. Paris, Sciences de la vie. 319: 595-602.

Sudharto, P.S., Purba, R.Y., Rochat, D., and, Morin J.P. (2001). Synergy between empty oil palm fruit bunch and synthetic aggregation pheromone (Ethyl 4methyloctanoate) for mass trapping of Oryctes rhinoceros beetles in the oil palm plantation in Indonesia. PORIM International Palm Oil Congress, Kuala Lumpur, Malaysia, Aug. 20-23.

Oehlschlager, A.C., Prior, R.N.B., Perez, A.L., Gries, R., Gries, G., Pierce, H.D. Jr., and, Laup, S. (1995). Structure, chirality, and field testing of a male-produced aggregation pheromone of Asian palm weevil Rhynchophorus bilineatus (Montr) (Coleoptera: Curculionidae). J. Chem. Eco. 21: 1619-1629.

Rochat, D., Ramirez-Lucas, P. Malosse, C., Aldana, R., Kakul, T., and, Morin, J. (2000). Role of solid phase microextraction in the identification of highly volatile pheromone of two Rhinoceros 
Beetles Scapanes australis and Strategus aloeus (Col., Scarabaeidae, Dynastinae). J. Chrom. A. 885: 433-444.

Prior, R. N. B., Morin, J. P., Rochat, D., BeaudoinOllivier, L., Stathers, T., Kakul, T., Embupa, S., Naguai, R. (2000). New aspects of the Biology of the Melanesian Rhinoceros beetle Scapanes australis (Col: Dynastidae) and Evidence for field attraction to males. J. Appl. Entomol. 124: 41-50. 